\title{
Short-term vasopressin analogue treatment does not influence the nitrogen balance in sheep
}

\author{
Š. Faix ${ }^{1,4}$, L. Leng1, J.J. Pająk², K. Boldižárová1, Z. Faixová ${ }^{3}$, \\ M. Czauderna ${ }^{2}$ and J. Kowalczyk ${ }^{2}$ \\ ${ }^{1}$ Institute of Animal Physiology, Slovak Academy of Sciences \\ Šoltésovej 4, 04001 Košice, Slovak Republic \\ ${ }^{2}$ The Kielanowski Institute of Animal Physiology and Nutrition, Polish Academy of Sciences \\ 05-110 Jablonna, Poland \\ ${ }^{3}$ Department of Pathological Physiology, University of Veterinary Medicine \\ Komenského 73, 04001 Košice, Slovak Republic
}

\begin{abstract}
The influence of vasopressin (dDAVP) on the nitrogen balance in 12 sheep, allotted to 2 groups of 6 , fed a daily ration containing $16.01 \mathrm{~g}$ of nitrogen, was examined. The experimental animals received $12.5 \mu \mathrm{g}$ dDAVP injected subcutaneously twice daily for 10 days before $\mathrm{N}$ balance was determined. Water intake and urine flow rate decreased due to dDAVP. The urine $\mathrm{N}$ concentration was significantly higher in the dDAVP group than in controls. Urinary and faecal $\mathrm{N}$ excretion and retained $\mathrm{N}(\mathrm{g} / \mathrm{d}$ and $\%$ of $\mathrm{N}$ intake) did not differ between groups. It is concluded that short-term administration of the vasopressin analogue does not affect the nitrogen balance in sheep.
\end{abstract}

KEY WORDS: nitrogen balance, vasopressin, sheep

\section{INTRODUCTION}

Our recent results with sheep injected with a vasopressin analogue (dDAVP) resulted in a $26 \%$ increase in the plasma urea, while renal urea reabsorption was concomitantly elevated by $63 \%$ (Boldižárová et al., 1999). This difference has been explained by extensive urea recycling into the digestive tract. The microbial population in the forestomachs enhances utilization of nitrogen from recycled

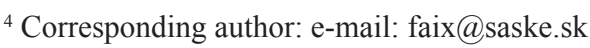


endogenous urea. Thus, the kidneys of ruminants contribute to a $\mathrm{N}$ saving mechanism for protein synthesis (Faixová et al., 1998). These data confirm the important role of the ruminant kidneys in nitrogen metabolism.

The aim of this experiment was to investigate the effects of vasopressininduced formation of highly concentrated urine on the nitrogen balance in sheep.

\section{MATERIAL AND METHODS}

The experiments were carried out on 12 wethers of 33 to $38 \mathrm{~kg}$ BW housed individually with free access to water and minerals, allotted to 2 groups of 6 . The control group was injected subcutaneously with $125 \mu \mathrm{l}$ of glycerol while the experimental one was given $12.5 \mu \mathrm{g}$ of a long-acting synthetic vasopressin analogue (1-desamino-8-D-arginine vasopressin, dDAVP, Adiuretin-SD, Ferring-Léčiva a.s., Prague) twice daily in $125 \mu \mathrm{l}$ of glycerol. Animals were adapted to the experimental ration (Table 1) for 3 weeks before the 10 day-dDAVP treatment followed by nitrogen balance measurements.

Table 1. Composition of daily ration for sheep

\begin{tabular}{lccc}
\hline & Feed, $g$ & Dry matter, g & Total N, g \\
\hline Hay & 500 & 440.0 & 8.67 \\
Barley & 300 & 263.1 & 5.26 \\
Rapeseed oilmeal & 40 & 36.3 & 2.08 \\
Total & 840 & 739.4 & 16.01 \\
\hline
\end{tabular}

Total faeces and urine were collected two times daily for 5 days. The urine samples were collected using a device described by Kowalczyk et al. (1996). Representative samples were taken at 8.00 a.m. and 8.00 p.m. for analysis. Jugular blood was sampled twice daily during each balance period into heparinized test tubes and stored in deep freeze until analysis. Diets, faeces, urine and blood were analysed for $\mathrm{N}$ according to AOAC (1980) methods.

Statistical significance was assessed by Student's t-test. The results are given as arithmetic means and standard error of means (SEM).

\section{RESULTS AND DISCUSSION}

No significant differences in blood urea concentrations were found between control and experimental animals $\left(6.5 \pm 0.3\right.$ vs $\left.7.1 \pm 0.4, \mathrm{mmol}^{-1}\right)$, respectively. Shortterm (10-day) administration of the vasopressin analogue resulted in significant reduction of water intake and urine flow rate and a significantly higher nitrogen 
concentration in the urine of experimental group animals (Table 2). No differences were found in nitrogen intake, faecal and urine nitrogen excretion between the control and experimental groups. The higher concentration of nitrogen in urine of animals treated with dDAVP was related to a lower urine flow rate, which was described earlier (Boldižárová et al., 1999).

Table 2. Nitrogen balance, mean values \pm SEM, $n=6$ for each group

\begin{tabular}{lccc}
\hline Indices & Control group & dDAVP group & P \\
\hline Daily feed intake, $\mathrm{g} \cdot$ day $^{-1}$ & $840 \pm 0$ & $840 \pm 0$ & $\mathrm{NS}$ \\
Nitrogen intake, $\mathrm{g} \cdot$ day $^{-1}$ & $16 \pm 0$ & $16 \pm 0$ & $\mathrm{NS}$ \\
Faeces, $\mathrm{g} \cdot$ day $^{-1}$ & $629 \pm 14$ & $644 \pm 15$ & $\mathrm{NS}$ \\
Faecal N, $\mathrm{g} \cdot$ day $^{-1}$ & $13.1 \pm 0.3$ & $13.6 \pm 0.5$ & $\mathrm{NS}$ \\
Water intake, $\mathrm{ml} \cdot$ day $^{-1}$ & $1596 \pm 74$ & $1305 \pm 81$ & 0.05 \\
Urine, $\mathrm{ml} \cdot$ day & $475 \pm 38$ & $272 \pm 42$ & 0.01 \\
Urine N concentration, $\mathrm{mg} \cdot \mathrm{ml}^{-1}$ & $3.8 \pm 0.8$ & $7.4 \pm 1.1$ & 0.05 \\
Urine nitrogen excretion, $\cdot$ day $^{-1}$ & $1.9 \pm 0.5$ & $1.9 \pm 0.3$ & $\mathrm{NS}$ \\
Total N excretion, \% N intake & $94 \pm 3$ & $97 \pm 3$ & $\mathrm{NS}$ \\
\hline
\end{tabular}

On the other hand, long-term treatment (5 months) with the same vasopressin analogue in growing lambs resulted in the relative enlargement of the kidney medulla and reduction in the size of the cortex. The surface area of the renal pelvis as a site of urea reabsorption was enlarged too. It was suggested that such vasopressin-induced changes in the kidneys of growing lambs could support more efficient renal recycling and subsequent reabsorption of urea into the blood stream (Bizup and Leng, 1997). Urea is known to be reabsorbed across the terminal inner medullary collecting duct by the vasopressin-regulated, facilitated urea transporter, UT-A1 (Artegaveytia et al., 2005). Vasopressin-induced urea transport is facilitated by a process acting via the adenylate cyclase-dependent pathway and activation of specialized urea transporters (Tsukaguchi et al., 1998). Ruminants have the ability to accumulate $\mathrm{N}$ by passive transfer of plasma urea by $\mathrm{N}$ recycling to the rumen and/or large intestine, where it can be used for synthesis of microbial protein (Boda et al., 1974). It has been documented that ruminants fed a low nitrogen diet are able to recycle a larger portion of endogenous urea into the digestive tract than animals on a high nitrogen intake (Havassy et al., 1974). Nonetheless, the vasopressin induced short-term formation of highly concentrated urine showed to be an insufficiently strong stimulator to increase the retention of nitrogen in our experimental sheep.

The results of this study show that 10-day long treatment of sheep with a vasopressin analogue had no effect on their nitrogen balance. 


\section{REFERENCES}

AOAC, 1980. Association of Official Analytical Chemists, Official Methods of Analysis. 13th Edition. Washington, DC

Artegaveytia N., Elalouf J.M., de Rouffignac C., Boivin R., Cirio A., 2005. Expression of urea transporter (UT-A) mRNA in papilla and pelvic epithelium of kidney in normal and low protein sheep. Comp. Biochem. Physiol. 140, 279-285

Bizup V., Leng L'., 1997. The effect of long-term administration of vasopressin on the development of the kidneys of growing lambs. Res. Vet. Sci. 62, 189-190

Boda K., Havassy I., Kowalczyk J., 1974. Retention of blood urea- ${ }^{15} \mathrm{~N}$ and its recirculation through the digestive tract of sheep. Abstracts of IV $^{\text {th }}$ International Symposium on Ruminant Physiology. Košice, p. 124

Boldižárová K., Faix Š., Leng L., 1999. The renal response of sheep fed a high protein diet to treatment with vasopressin analogue. Acta Vet. Brno 68, 99-104

Faixová Z., Levkut M., Kolodzieysky L., Faix Š., Leng L', 1998. The distribution of enzymes in the kidneys of sheep fed a high and low protein diet. Acta Vet. Brno 67, 83-87

Havassy I., Boda K., Kosta K., Rybosova E., Kuchar S., 1974. Retention of intravenously administered ${ }^{15} \mathrm{~N}$-labelled urea in sheep. Physiol. Bohemoslov. 23, 297-304

Kowalczyk J., Skiba B., Buczkowski Z., Kowalik B., 1996. A device for quantitative urine collection from male sheep in balance trials. J. Anim. Feed Sci. 5, 297-301

Tsukaguchi H., Shayakul Ch., Berger U., Hediger M.A., 1998. Urea transporters in kidney: molecular analysis and contribution to the urinary concentrating process. Amer. J. Physiol. 275, F319-F324

\section{STRESZCZENIE}

\section{Krótkoterminowe podawanie analogu wazopresyny nie wpływa na bilans azotu u owiec}

Badano wpływ podawanej podskórnie sześciu owcom pochodnej wazopresyny (dDAVP) w ilości 12,5 $\mu \mathrm{g}$ każdorazowo, dwa razy dziennie przez 10 dni. Grupa kontrolna owiec nie otrzymywała dDAVP. Owce obydwóch grup były żywione jednakowo. Ilość pobranej wody oraz ilość wydalanego moczu były istotnie mniejsze, natomiast stężenie azotu w moczu większe u owiec grupy doświadczalnej niż kontrolnej. Ilość azotu wydalana w kale i moczu oraz retencja $\mathrm{N}$ (g/d oraz \% pobranego $\mathrm{N}$ ) nie różniły się miedzy grupami co świadczy, że podanie owcom analogu wazopresyny nie wpływa na retencję azotu. 